TARNOWSKIE STUDIA TEOLOGICZNE 37 (2018) NR 1-2, S. 231-246 http://dx.doi.org/10.15633/tst.326o

ks. Robert Kantor ${ }^{1}$

UNIWERSYTET PAPIESKI JANA PAWŁA II W KRAKOWIE

\title{
Instytucja zaręczyn w ujęciu ks. Józefa Pelczara na podstawie prawa katolickiego
}

Ksiądz Józef Sebastian Pelczar, późniejszy biskup, podjął pracę na Uniwersytecie Jagiellońskim w okresie, kiedy uczelnia dźwigała się z upadku spowodowanego wydarzeniami z 1846 roku i germanizacją uczelni. Dwaj profesorowie, którzy przybyli z Przemyśla: ks. Krukowski i ks. Pelczar, zastali na wydziale teologicznym tylko dwóch profesorów zwyczajnych, niechętnych wszelkim zmianom. „Moim głównym zadaniem - pisał ks. Pelczar - było zatem wyjednać u rządu reorganizację wydziału teologicznego, ściągnąć z różnych stron ludzi zdolnych na profesorów [...] wreszcie nawiązać dobre stosunki z profesorami świeckimi”2. Pelczarowi zależało na zmianie sposobu nauczania. Dawna metoda naukowa, polegająca na dyktowaniu studentom skrótów wiadomości z nieaktualnych podręczników, nie była już wystarczająca. Jego zdaniem wykłady powinny być prowadzone $\mathrm{w}$ sposób interesujący, a przekazywane wiadomości powinny być aktualizowane w miarę rozwoju danej dziedziny. Należało większą uwagę przywiązywać do zrozumienia przez studentów wykładanego problemu i do kształtowania ich samodzielnego myślenia niż do pamięciowego opanowania materiału ${ }^{3}$.

\footnotetext{
Ks. Robert Kantor, doktor habilitowany nauk prawnych w zakresie prawa kanonicznego. Studia na Wydziale Prawa Kanonicznego Uniwersytetu Navarry w Pampelunie. Kierownik Katedry Teologii Praktycznej i Prawa Kanonicznego na Wydziale Teologicznym Sekcja w Tarnowie UPJPII w Krakowie. W latach 2002-2010 wykładowca prawa kanonicznego w Wyższym Seminarium Duchownym w Gródku Podolskim na Ukrainie agregowanym do Uniwersytetu Laterańskiego w Rzymie; sędzia Sądu Diecezjalnego w Tarnowie. Od 2014 roku kanclerz Kurii Diecezjalnej w Tarnowie; sekretarz czasopisma naukowego „The Person and the Challenges”; redaktor naczelny „Currendy” - urzędowego pisma diecezji tarnowskiej. Autor wielu książek i artykułów z prawa kanonicznego i wyznaniowego.

2 J. S. Pelczar, Wybór pism (Krótka kronika mojego życia, Listy), „Nasza Przeszłość” 29 (1968), s. 90-91.

3 M. Ludwicki. Biskup, rzecz o św. Józefie Sebastianie Pelczarze, Ząbki 2004, s. 57.
} 
Niniejszy artykuł jest przykładem wzorcowego wyłożenia tematu przez ks. Pelczara w oparciu o aktualnie obowiązującą doktrynę prawną oraz odpowiednie kazusy ułatwiające zrozumienie tematu. Podstawowym źródłem pracy jest podręcznik ks. Józefa Sebastiana Pelczara pt. Prawo małżeńskie katolickie z uwzględnieniem prawa cywilnego obowiązującego w Ausryi, w Prusach $i$ Królestwie Polskim wydany w Krakowie w 1898 roku. Na treść przedłożenia składają się następujące kwestie związane $\mathrm{z}$ instytucją zaręczyn: wymogi do ważności zaręczyn, forma przyrzeczenia podczas zaręczyn, rodzaje zaręczyn, skutki zawartych zaręczyn, zerwanie zawartych zaręczyn, zadania proboszcza przy zawieraniu zaręczyn, rola sądu małżeńskiego w sprawach zaręczyn, odszkodowanie $\mathrm{z}$ powodu zerwania zaręczyn.

Celem artykułu jest przybliżenie czytelnikowi instytucji zaręczyn widzianych z perspektywy wykładowcy Uniwersytetu Jagiellońskiego, późniejszego rektora tejże uczelni (1882/1883), biskupa i od 2003 roku świętego - Józefa Sebastiana Pelczara.

\section{Wymogi do ważności zaręczyn}

Zaręczyny to obopólna umowa, mocą której mężczyzna i kobieta przyrzekają zaślubić się z sobą w przyszłości. Umowa ta odnosi się do przyszłego małżeństwa i jest nie tylko obustronnym wyjawieniem chęci pobrania się, ale także zobowiązaniem się do zawarcia małżeństwa. Instytucja ta była znana już w świecie przedchrześcijańskim u Żydów, Greków i Rzymian. Aktowi temu towarzyszyły m.in. błogosławieństwo kapłańskie, spisanie kontraktu, wręczenie podarunków, pierścienia, podanie prawej ręki, pocałunek ${ }^{4}$.

Zdaniem ks. Pelczara zaręczyny jako akt przygotowawczy podlegają władzy Kościoła, stąd prawo kościelne określa warunki konieczne do ważnego zawarcia zaręczyn:

1. Z powodu ogólnej niezdolności do działań prawnych nie mogą zawrzeć ważnych zaręczyn:

- chorzy na umyśle, czyli obłąkani i idioci. Zaręczyny zawarte przez obłąkanych w chwili odzyskania przez nich przytomności są ważne, ale nie są „dozwolone" (illicita). W przypadku wątpliwości przypuszcza się, że stan obłąkania trwa bez przerwy;

4 J. Pelczar, Prawo małżeńskie katolickie z uwzględnieniem prawa cywilnego obowiązującego w Ausryi, w Prusach i w Królestwie Polskim, Kraków 1898, s. 73-74. 
- pijani i zostający pod wpływem jakiejś gwałtownej namiętności nie mogą zawrzeć ważnych zaręczyn, jeśli pijaństwo lub namiętność pozbawiła ich używania rozumu;

- głusi, niemi i ślepi zarazem nie mogą zawrzeć zaręczyn, nie mogą bowiem pojąć ich znaczenia, ani też wyrazić swego zezwolenia. Wyjątkiem jest sytuacja, jeśli ktoś później popadł w to potrójne kalectwo i zdoła w jakiś sposób, np. pismem wyrazić swoją wolę;

- dzieci niemające ukończonych siedmiu lat nie mogą ważnie zawrzeć zaręczyn, gdyż według powszechnego zdania dopiero ukończenie siedmiu lat jest porą, w której przychodzi używanie rozumu. Osoba niedojrzała (impubes) mająca wprawdzie lat siedem, ale niemająca lat dojrzałości, czyli 14 lat skończonych, jeżeli to jest chłopiec, a 12 skończonych, jeżeli to jest dziewczyna, może ważne zawrzeć zaręczyny, bądź przez siebie, bądź przez swoich rodziców; lecz w takim przypadku zerwać zaręczyn nie może, dopóki nie dojdzie do lat dojrzałości. Po osiągnięciu tego wieku wolno jej bez żadnej przyczyny i nawet wbrew woli drugiej strony odstąpić od zaręczyn.

2. Z powodu zachodzącej przeszkody nie mogą zawrzeć ważnych zaręczyn ci wszyscy, którym przeszkoda kanoniczna czy rozrywająca, czy tamująca wzbrania zawarcia ważnego lub godziwego małżeństwa. Chodzi tu o zasadę, że przyrzeczenie rzeczy niemożliwej lub „niedozwolonej” nie ma żadnej mocy. Jeżeli przeszkoda nie da się usunąć, jako pochodząca z prawa przyrodzonego lub Boskiego, zaręczyny są nieważne. Jeżeli przeszkoda dałaby się usunąć w wyniku dyspensy papieskiej, mimo trudności, gdyż papież w podobnym wypadku nader rzadko dyspensuje (impedimentum ordinis lub voti solemnis), albo jeżeli nie ma słusznej przyczyny, zaręczyny są nieważne. Jeżeli przeszkoda dałaby się usunąć, gdyż i papież zwykł w takim przypadku dyspensować i istnieją przyczyny kanoniczne, strony zawierają zaręczyny bezwarunkowe, wówczas zaręczyny są nieważne. Jednak, jak zauważa ks. Pelczar „Jeżeliby w ostatnim wypadku strony zawały zaręczyny pod warunkiem wyraźnym lub milczącym, natenczas według zdania wielu teologów i kanonistów (św. Tomasz z Akwinu, Sanchez, Alfons Liguori, Scavini, Gasparri) umowa ta ma moc warunkowych zaręczyn; a chociaż z nich nie wynika przeszkoda publicae honestatis, jak długo warunek nie został zniszczony, to jednak strony obowiązane są prosić o dyspensę i czekać na wyrok papieski. Po otrzymaniu dyspensy zaręczyny stają się bezwzględnie ważnemi i nie potrzeba ponawiać przyrzeczenia, byleby takowe nie zostało odwołane. Gdyby jedna ze stron tak zaręczonych przed otrzymaniem dyspensy inne zawarła zaręczyny, natenczas według zdania przytoczonych teologów, 
te drugie zaręczyny byłyby nieważne. Zdanie to opiera się na zasadzie: actus factus tempore inhabili, relatus ad tempus habile valet pro illo"s.

W ramach przeszkód i ich wpływu na ważność zaręczyn można wymienić jeszcze:

- Nieważne są zaręczyny między osobą ochrzczoną i nieochrzczoną, gdyż z powodu przeszkody cultus disparitatis związek małżeński między tymi osobami byłby nieważny;

- Nieważne są zaręczyny między osobą katolicką i akatolicką, w razie, gdyby strony nie chciały dopełnić przepisanych przez Kościół warunków i prosić o dyspensę, nikt nie może obiecywać pod grzechem rzeczy wzbronionej;

- Nieważne i grzeszne są zaręczyny między osobą związaną węzłem małżeńskim i osobą wolną;

- Nieważne są zaręczyny w przypadku, gdyby strony się umówiły, że zawrą ślub bez przystąpienia do sakramentów świętych, bez zachowania obrzędów przez Kościół przepisanych.

5 J. Pelczar, Prawo małżeńskie katolickie, s. 79. Jak podkreśla ks. Pelczar, niektórzy kanoniści (Barbosa, De Luca, De Nicollis, Schulte, Kutschker, Vering) sądzą, że zaręczyny w takim przypadku są bezwzględnie nieważne, gdyż zachodząca przeszkoda niezdolnym czyni nie tylko ad contrahendum, ale także ad promittendum; stąd każda ze stron może przed otrzymaniem dyspensy zawrzeć ważnie inne zaręczyny, pierwsza bowiem umowa do niczego nie obowiązywała, jak tylko do podania prośby o dyspensę; po otrzymaniu tejże należy ponowić przyrzeczenie. Dla poparcia swego zdania powołują się na decyzje Roty Rzymskiej. W tym temacie ks. Pelczar przytacza kazus sprawy Januensis: „18 lipca 1733 Juliusz Pallavicini i Aniela Marya Zoaglia, spokrewnieni z sobą w czwartym stopniu, zawarli zaręczyny, a dwa dni później umocnili takowe przysięgą i w akcie spisanym dodali klauzulę, że się postarają o dyspensę. Zapewne Aniela tych związków wielce pragnęła, bo jeszcze przed zawarciem zaręczyn, a bez wiedzy Pallaviciniego, postarała się w Rzymie o dyspensę, która już 15 lipca podpisaną została. Nim atoli takowa nadeszła, zawarł Pallavicini 26 lipca tego roku inne zaręczyny z Maryą Ter. Gropalla i zażądał od kuryi arcybiskupiej pozwolenia na zaślubienie tejże. Natomiast Aniela wystąpiła ze skargą o nieprawne zerwanie pierwszych zaręczyn, aby zaś dowieść ich ważności, powołała się na to, że dyspensa papieska już 15 lipca wydana została, że zatem zaręczynom zawartym 18 lipca nic nie stało na zawadzie. Zaprzeczył temu Pallavicini, wykazując, że reskrypt papieski poleca delegatowi po zbadaniu rzeczy egzekwować dyspensę; skoro to jednak nie nastąpiło, przeto przeszkoda nie została jeszcze zniesiona. Sprawa ta wytoczyła się wreszcie przed św. Kongregacyją Concilii, która dnia 12 grudnia 1733 na pytanie: an sponsalia inter Angelam Mariam Zoagliam et Julium Pallavicinum inita sustineantur, odpowiedziała: Negative et amplius, to jest, uznała zaręczyny pierwsze za nieważne i nie pozwoliła sporu tego ponawiać” (J. Pelczar, Prawo małżeńskie katolickie, s. 8o). 


\section{Forma przyrzeczenia podczas zaręczyn}

Co do samej formy przyrzeczenia, to ks. Pelczar w swoim podręczniku przytacza kilka cech, jakie winna ona spełniać.

1. Przyrzeczenie powinno być prawdziwe, tzn. płynące z postanowienia woli i związane z zamiarem dotrzymania słowa. Przyrzeczenie udane lub żartobliwe nie ma mocy zaręczyn. Przyrzekający w taki sposób grzeszy ciężko przeciw sprawiedliwości i obowiązany jest do naprawienia krzywdy, jeżeli taka wyniknęła. Na forum zewnętrznym domniemywa się, na podstawie domniemania prawnego, że przyrzeczenie było prawdziwe dopóki poprzez świadków lub przysięgę nie udowodni, że był to tylko żart lub udawanie ${ }^{6}$.

2. Przyrzeczenie winno być uczynione z rozwagą i dobrowolnie, czyli przyrzekający winien wiedzieć, co czyni i mieć zamiar zobowiązania się i być wolnym od przymusu i pomyłki. Gdyby przymus lub strach był tak wielki, że unieważnia małżeństwo, zaręczyny byłyby ex se nieważne, choćby były stwierdzone pod przysięgą. Podobnie jest w przypadku zaręczyn między porywającym

${ }^{6}$ J. Pelczar, Prawo małżeńskie katolickie, s. 83. Ksiądz Pelczar na potwierdzenie tezy o prawdziwości zaręczyn przytacza kazus: „Niejaki Anioł Confone wszedłwszy w nocy i to siłą do mieszkania Anny Ferraco, zaledwie 14 lat mającej, dopuścił się haniebnego gwałtu. By pocieszyć nieszczęśliwą, przyrzekł jej pod przysięgą, że się z nią ożeni, a tę obietnicę przez nią przyjętą, później po kilkakroć, nawet przy świadkach ponowił. Po upływie pięciu lat od onej nocy zerwał z Anną Ferraco, głównie w skutek oporu swego ojca i do innej się zwrócił. Tedy Anna pozwała go przed trybunał wikariusza generalnego, który pod dniem 1 maja 1832 wydał wyrok tej treści, że Anioł Confone obowiązany jest pojąć Annę Ferraco za małżonkę i że wszelkie inne przezeń zamierzone zaręczyny byłyby nieważne. Ponieważ jednak January, ojciec oskarżonego, odwołał się do Ojca Świętego, przeto sprawa cała przeszła do Kongregacyi S. Concilii. Obie strony wystąpiły w swej obronie. Confone nie wypierał się gwałtu popełnionego, dochodził jednak, że zaręczyny z Anną nie były ważne, jako dokonane w chwili namiętności, a przynajmniej, że mu wolno od nich odstąpić z powodu oporu rodziny; natomiast okazał się skorym do wypłacenia posagu uwiedzionej. Anna zaś stwierdziła świadkami, do których nie sami jej krewni lub powinowaci należeli, że zaręczyny rzeczywiście zostały zawarte i przysięgą umocnione, że takowe nie były udane, że Confone nie ma żadnego powodu do ich zerwania, że prawo w takim wypadku każe dotrzymać obietnicy, że wreszcie sama Kongregacya Concilii w podobnych wypadkach nie inaczej rozstrzygała. Po zbadaniu sprawy na pytanie: 1) an constet de sponsalibus inter Angelum Confone et Annam Rerraco in casu; et quatenus affirmative, 2) an Confonius cogendus sit ad matrimonium cum ea ineundum vel potius assignata eidem dote possit a contractis sponsalibus recedere in casu? Odpowiedziała Święta Kongregacya 27 lutego 1736 ad. 1) Affirmative, Ad 2) Affirmative ad primam partem, juxta sententiam Vicarii generalis; negative ad secundum" (J. Pelczar, Prawo małżeńskie katolickie, s. 84). 
i porwaną; jak długo porwana jest w mocy porywającego, zaręczyny byłyby nieważne.

3. Przyrzeczenie powinno być obopólne, czyli jedna strona winna przyrzec, z kolei druga tę obietnicę przyjąć i to samo przyobiecać. Ksiądz Pelczar twierdzi, że „wymaga się tego, aby jedna i druga strona dała swe przyrzeczenie w tym samym czasie, iżby stąd wyniknęła wzajemna umowa; gdyby bowiem np. Jan przyrzekał Annie, że się z nią ożeni, Anna zaś nic w tej chwili nie odpowiedziała i dopiero po kilku dniach taką samą dała obietnicę Janowi: zaręczyny nie byłyby zawarte, gdyż tu promissio nie schodzi się cum repromissione; chyba że Jan zobowiązał się czekać na odpowiedź Anny i tymczasem nie zmienił swego postanowienia”. W tym kontekście z pomocą przychodzi orzecznictwo Kongregacji Soboru z 17 grudnia 1881 roku: „Niejaki Kozma, porzuciwszy Teresę, z którą miał stosunek wcale nie platoniczny, chciał poślubić Gracyę. Teresa wniosła do proboszcza, a następnie do ordynaryatu biskupiego skarge przeciw zamierzonemu związkowi, dowodząc, że między nią a Kozmą zawarte zostały zaręczyny. Ordynaryat orzekł, że nie było tu zaręczyn dla braku obopólnego przyrzeczenia, czyli promisyi ze strony Teresy. Atoli sąd metropolitalny, do którego ona zaapelowała, rozstrzygnął na jej korzyść, który to wyrok zatwierdziła Święta Kongregacja Concilii, na tej mianowicie podstawie, że zezwolenie na utratę panieństwa, dane przez uczciwą pierw dziewczynę, należy uważać za wzajemne przyrzeczenie" ${ }^{\text {. }}$.

4. Przyrzeczenie winno być wyjawione na zewnątrz za pomocą słów, pisma, znaków lub czynności. Słowa powinny być jasne, czyli zawierać niedwuznaczną obietnicę zaślubienia drugiej strony. „Słowa ciemne, niedorzeczne, żartobliwe i w szale namiętności wyrzeczone (np. zapewnienia miłości i wierności dozgonnej) nie wchodzą wcale w rachubę. A więc nie ma zaręczyn, jeśli ktoś mówi: przenoszę cię nad wszystkie; jeśli się kiedyś ożenię, to tylko z tobą"”. Podobnie znaki winny być objawem wewnętrznej woli. Do takich znaków należy wręczenie i przyjęcie pierścienia. Zewnętrzną formą przyrzeczenia zaręczyn może być list, poseł lub prokurator, ale w takim przypadku ma być rzeczą jasną i pewną, że obie strony chcą zawrzeć małżeństwo ${ }^{10}$.

\footnotetext{
7 J. Pelczar, Prawo małżeńskie katolickie, s. 86.

8 „Acta Sanctae Sedis” fasc. II, vol. xv. Cyt. za J. Pelczar, Prawo małżeńskie katolickie, s. 87.

9 J. Pelczar, Prawo małżeńskie katolickie, s. 87.

${ }^{10} \mathrm{~J}$. Pelczar, Prawo małżeńskie katolickie, s. 88.
} 
5. Przyrzeczenie winno być dane na czas przyszły. Winno być też niedwuznaczne co do osób, czyli powinno odnosić się do osoby pewnej i indywidualnie oznaczonej. Gdyby ktoś wobec trzech sióstr oświadczył, że jedną z nich weźmie za żonę, zaręczyn by nie było ${ }^{11}$.

\section{Rodzaje zaręczyn}

Ksiądz Pelczar ze względu na samo zobowiązanie rozróżnia zaręczyny bezwarunkowe i warunkowe. Jego zdaniem warunki mogą być różnego rodzaju:

1. Warunek przeciwny istocie małżeństwa. „Np. poślubię cię, ale tak, że nie będziesz miała żadnego prawa in corpus meum, jako też warunek a) contra bonum prolis (np. przyrzekam poślubić cię, jeżeli przed ślubem staniesz się niepłodną, albo jeżeli się zobowiążesz ad abortum), b) contra bonum fidei (np. przyrzekam poślubić cię, jeżeli się puścisz na życie rozpustne), c) contra bonum Sacramenti (np. przyrzekam poślubić cię, jeżeli po trzech latach pożycia przestaniesz być moją żoną)”'12. Sytuacje przedstawione powyżej unieważniają małżeństwo oraz zaręczyny.

2. Warunek nieuczciwy lub niemożliwy. „Co do zaręczyn warunek fizycznie lub moralnie niemożliwy, a do tego dodatni (np. przyrzekam poślubić cię, jeżeli mi gwiazdkę z nieba ściągniesz, albo jeżeli przed ślubem dopuścisz się porubstwa), czyni takowe nieważnym. $Z$ tejże przyczyny nieważne jest przyrzeczenie dane przez osobę związaną ślubem małżeńskim osobie wolnej, aczby pod warunkiem: jeżeli mąż (lub żona) umrze. Co więcej, osoby te grzeszą ciężko"'13.

3. Jeżeli warunek postawiony przy zawieraniu zaręczyn jest możliwy i uczciwy, lecz zarazem zawieszający, np. poślubię cię, jeżeli odziedziczysz majątek wówczas zaręczyny pozostają w zawieszeniu, jak długo warunek się nie spełni.

4. Warunek de praesenti lub de praeterito nie ma mocy zawieszającej. W takim przypadku zaręczyny są ważne lub nie w zależności od tego czy warunek istnieje czy nie.

5. Warunek znoszący sprzeciwia się bono Sacramenti, czyli istocie małżeństwa, które raz ważnie zawarte, nie może być rozerwane według woli stron ${ }^{14}$.

\footnotetext{
${ }^{11}$ J. Pelczar, Prawo matżeńskie katolickie, s. 89.

${ }_{12}$ J. Pelczar, Prawo małżeńskie katolickie, s. 92.

13 J. Pelczar, Prawo matżeńskie katolickie, s. 93.

${ }^{14}$ J. Pelczar, Prawo małżeńskie katolickie, s. 94.
} 


\section{Skutki zawartych zaręczyn}

Pierwszym skutkiem ważnych zaręczyn - zdaniem ks. Pelczara - jest obligatio sponsalia. Chodzi o dochowanie sobie wiary ex iustitia. „W stosunkach obopólnych winni narzeczeni przestrzegać wszelkiej przyzwoitości, i nie sądzić, jakoby niektóre poufałości, np. oscula lub amplexus, były im pozwolone. Dla usunięcia niebezpiecznych okazyi należy im polecić: 1/ aby mieszkali osobno i nie przebywali sam na sam, ale w obecności krewnych lub innych osób; 2 / aby ślubu małżeńskiego nie odwlekali, gdyż podobna zwłoka sprowadza nieraz ciężkie upadki i zgorszenia; 3 / aby tymczasem nabywali znajomości religii i ćwiczeniami pobożnemi usposabiali się do godnego przyjęcia Sakramentu; 4/ aby zawczasu (np. przed pierwszą zapowiedzią) dobrą, i jeżeli można, generalną odprawili spowiedź, iżby łatwiej było wykryć i usunąć tajemne przeszkody”15. Ponadto obligatio sponsalia wymaga, aby narzeczeni ściśle według umowy zawarli ze sobą ślub małżeński.

Po drugie, $\mathrm{z}$ ważnych zaręczyn wynika przeszkoda tamująca, mocą której żadna $\mathrm{z}$ osób zaręczonych nie może zawrzeć innego małżeństwa lub innych zaręczyn. „Małżeństwo z trzecią osobą zawarte, bez względu na to czy ratum, czy i consumatum, byłoby wprawdzie ważne, ale nie dozwolone; zaręczyny zaś drugie byłyby i nie dozwolone i nieważne, choćby nawet były umocnione przysięgą"

Po trzecie z zaręczyn ważnie zawartych wynika przeszkoda unieważniająca publicae honestatis. Przeszkoda ta nie pozwala zawrzeć ważnego małżeństwa między narzeczonym i krewnymi narzeczonej w pierwszym stopniu oraz między narzeczoną i krewnymi narzeczonego również w pierwszym stopniu ${ }^{17}$.

Wreszcie czwartym skutkiem ważnie zawartych zaręczyn według ks. Pelczara było - przed soborem trydenckim - to, iż ,jeżeli po nich następowała libera et perfecta copula carnalis, tedy sponsalia de futuro, ale tylko ważne, przechodziły w sponsalia de praesenti, czyli stawały się małżeństwem, a to na podstawie domniemania prawnego, że copula subsequens oznacza zezwolenie de praesen$t i^{\prime 18}$. Zatem, jeżeli po zaręczynach miało miejsce pełne współżycie seksualne, oznaczało to zgodę na małżeństwo.

\footnotetext{
15 J. Pelczar, Prawo matżeńskie katolickie, s. 102.

${ }^{16}$ J. Pelczar, Prawo małżeńskie katolickie, s. 105.

${ }^{17}$ J. Pelczar, Prawo matżeńskie katolickie, s. 106.

18 J. Pelczar, Prawo małżeńskie katolickie, s. 106.
} 


\section{Zerwanie ważnych zaręczyn}

Ważnie zawarte zaręczyny, czyli spełniające wszystkie wymagane warunki, mogą być w pewnych sytuacjach rozwiązane. Może to nastąpić w taki sposób, że zaręczyny przestaną obowiązywać obydwie strony lub tylko jedną.

W pierwszym przypadku zrywa zaręczyny:

1. Śmierć jednej strony.

2. Obopólna zgoda. W tym przypadku wymagany jest słuszny powód oraz by zerwanie nie było powodem wymuszonego strachu.

3. Przeszkoda rozrywająca lub tamująca zaciągnięta po zawarciu zaręczyn. Taką przeszkodą może być niemoc płciowa, małżeństwo zawarte z osobą trzecią ${ }^{19}$, wyższe święcenia, złożenie ślubów uroczystych, rotum simplex ingrediendi religionem, suscipiendi ordines sacros, perpetue castitatis, superveniens affinitas illegitima.

4. Warunek spełniony rozrywa zaręczyny, jeżeli te były zawarte sub conditione resolutiva. Tak np. zaręczyny warunkowe: poślubię cię, jeżeli nie będzie wojny, tracą moc obowiązującą dla obu stron w razie wybuchu wojny. Jeżeli to był warunek zawieszający zaręczyny, tak długo nie są ważne, jak długo warunek nie będzie spełniony ${ }^{20}$.

W drugim przypadku mogą wystąpić powody, dla których wolno jednej stronie odstąpić od zaręczyn:

1. Jeżeli jedna strona staje się wiarołomną, a mianowicie:

- jeżeli z trzecią osobą zawiera zaręczyny, które w takim przypadku są nieważne;

- jeżeli bez słusznej przyczyny jedna ze stron nie trzyma się oznaczonego terminu, albo zbyt długo odwleka zawarcie małżeństwa;

- jeżeli bez pozwolenia drugiej osoby oddala się w obce strony, by stamtąd nie wrócić, albo opóźnić powrót;

${ }_{19}$ W tym wypadku ustaje obowiązek dla strony oszukanej czy ustaje dla strony winnej? „Jedni sądzą, że zobowiązanie na zawsze ustaje; natomiast według św. Alfonsa Liguoriego probabilior est sententia, obligationem sponsaliam, durante matrimono, non exstingui sed suspendi (Homo apost. tr. 18, n. 13), tak, że po zerwaniu małżeństwa przez śmierć odzyskują moc swoją zaręczyny; rozumie się, jeżeli druga strona prawa swego się nie zrzekła. Tem więcej, gdyby to małżeństwo było nieważnem, strona winna byłaby obowiązana dotrzymać pierwszego przyrzeczenia, podczas gdy niewinna mogłaby i w tym razie prawnie odstąpić” (J. Pelczar, Prawo matżeńskie katolickie, s. 108).

${ }^{20}$ J. Pelczar, Prawo małżeńskie katolickie, s. 110. 
- jeżeli z trzecią osobą nawiązuje niegodziwe stosunki. Jeżeli narzeczona została przemocą zmuszona do grzechu, narzeczony mimo to może odstąpić. Jeżeli uczynek nastąpił przed zawarciem zaręczyn, a narzeczony dowiedział się o tym po zaręczynach, wolno mu zaręczyny zerwać. Takie samo prawo przysługuje narzeczonej, zwłaszcza gdy upadki narzeczonego były częste, tak, że ten stał się podejrzany o skłonności do lubieżności, albo gdy z poprzednich stosunków pozostały dzieci. Jeżeli obie strony złamały wiarę, według niektórych teologów obie pozostają wolne.

2. Wolno zerwać zaręczyny, jeżeli w stosunkach zaręczonych taka zajdzie zmiana, albo dopiero po zaręczynach zostanie odkryta, iż zaręczyny nie doszłyby do skutku. Zmiana taka może zajść:

- co do ciała. Trąd, paraliż, utrata wzroku lub nosa upoważnia drugą stronę do zerwania zaręczyn, choćby zaprzysiężonych. Podobnie rzecz się ma z chorobą zaraźliwą lub niezaraźliwą, wszelkim kalectwem, które utrudnia pożycie małżeńskie. Choroba ciężka, tym bardziej nieuleczalna, uwalnia nie tylko zdrową osobę, ale i chorą od obowiązku zaciągniętego w zaręczynach;

- co do duszy. Jeżeli jedna strona dostaje obłąkania, fiksacji lub ponurej melancholii, wolno drugiej osobie zerwać zaręczyny;

- co do religii. Jeżeli jedna osoba wpada w herezję, przechodzi na judaizm, mahometanizm etc., wyrzeka się wszelkiej wiary i ogłasza się za bezwyznaniową;

- co do moralności. Jeżeli jedna osoba oddaje się występkom, jak np. pijaństwo, jeżeli dopuszcza się zbrodni lub wykroczeń ściągających niesławę, jeżeli zapisuje się do towarzystw zakazanych, jak np. socjalistów, wolnomularzy, jeżeli okazuje się gwałtowną, złośliwą;

- co do majątku. Jeżeli jedna osoba trwoni majątek skutkiem lenistwa, gry w karty, jeżeli popadła w długi lub ubóstwo, albo od początku nic nie miała tylko udawała, że coś ma, jeżeli utraciła posag, jeżeli zachodzi obawa wydziedziczenia. We wszystkich tych przypadkach tylko strona pokrzywdzona, czyli ta, która wskutek zaszłej lub odkrytej zmiany ucierpiała, może zerwać zaręczyny. Jeżeli poznawszy tę zmianę, utrzymuje nadal stosunek wynikający $\mathrm{z}$ zaręczyn, a co więcej, jeżeli z drugą strona popełnia copulam carnalem, wtedy zrzeka się swego prawa.

3. Zaręczyny mogą być zerwane, jeżeli zachodzą takie okoliczności, że małżeństwo byłoby z pewnością nieszczęśliwe. Mogło się tak zdarzyć w przypadku, gdyby jedna ze stron żywiła do drugiej wielką niechęć, i w żaden sposób, nawet pod groźbą sankcji karnej, nie można było jej skłonić do zawarcia małżeństwa. Jak zauważa ks. Pelczar, „podobnie, jeżeli rodzice (ewentualnie opiekunowie) 
słusznie się opierają związkom małżeńskim swoich dzieci, i lękać się trzeba niesnasek domowych, albo nawet wydziedziczenia: mogą być zaręczyny zerwane, czy to przez strony, czy przez sędziego duchownego. Lecz i w takim razie może strona opuszczona żądać wynagrodzenia. [...] Jeżeli powód do zerwania zaręczyn jest jawny i pewny, tedy wolno je zerwać. Jeżeli powód jest pewny, ale tajemny, wolno jest zerwać zaręczyny tajemnie, do zerwania zaś jawnego potrzeba wyroku sądowego, w razie gdy druga strona sprzeciwia się zerwaniu. Jeżeli powód jest pewny, ale niepodobna udowodnić go przed sądem, może strona niewinna ze spokojnem sumieniem odstąpić, byleby stąd nie powstało zgorszenie" ${ }^{21}$.

\section{Zadania proboszcza przy zawieraniu zaręczyn}

Ksiądz Pelczar postuluje, by proboszcz z ambony uświadamiał swoich wiernych o instytucji zaręczyn i o samym sakramencie małżeństwa. Zadania proboszcza sprowadza do kilku:

- winien ostrzegać młodych, by nie zawierali zaręczyn lekkomyślnie, w szale namiętności, w stanie nietrzeźwym, bez świadków, bez zamysłu, bez wiedzy i zezwolenia rodziców;

- winien upominać rodziców, by z powodu dumy, kaprysu lub interesu nie decydowali o szczęściu swoich dzieci;

- winien starć się, aby zaręczyny odbywały się wobec rodziców, świadków i jego samego;

- winien pouczać zaręczonych o ich wzajemnych obowiązkach, o skutkach zaręczyn i przeszkodach, by nie mieszkali razem, by nie odkładali ślubu;

- jeżeli proboszcz dowiaduje się (nie ze spowiedzi), że ktoś po zawarciu ważnych zaręczyn, chce z trzecią osobą wejść w związek małżeński, winien $z$ urzędu, jeszcze przed ogłoszeniem zapowiedzi zbadać sprawę;

- w przypadku, gdy proboszcz wątpi, czy zaręczyny pierwsze są ważne czy nie, nie może głosić zapowiedzi, a co za tym idzie nie może zezwolić na zawarcie ślubu między stroną oskarżoną i trzecią osobą. Wtedy winien rzecz lepiej zbadać, a gdyby mu się nie udało skłonić stron do zgody, powinien odnieść się do sądu małżeńskiego ${ }^{22}$.

${ }^{21}$ J. Pelczar, Prawo małżeńskie katolickie, s. 115-116.

${ }^{22}$ J. Pelczar, Prawo małżeńskie katolickie, s. 117-119. 


\section{Rola sądu małżeńskiego w sprawach zaręczyn}

Zgodnie z dyspozycjami Soboru Trydenckiego, ponieważ zaręczyny są wstępem do małżeństwa, sprawy dotyczące istnienia, ważności i skutków zaręczyn należą ad causas matrimoniales i podlegają wyłącznie sądom kościelnym. Sędzią w tych sprawach jest biskup diecezjalny ${ }^{23}$, wspomagany przez sąd małżeński. Sąd ten działa w sprawach dotyczących zaręczyn jedynie na żądanie stron, gdy jedna z nich żąda dotrzymania umowy, a druga przeczy jej ważności, lub przyznaje sobie słuszne prawo do jej zerwania. Zwykle strona opuszczona występuje ze skargą, którą sędzia w niektórych przypadkach może odrzucić, np. jeżeli strona przez kilka lat milczała, a teraz wnosi skargę nie tylko w celu obrony swoich praw, ale także wstrzymania małżeństwa i zniesławienia drugiej strony. Postępowanie w sprawach odnoszących się do zaręczyn powinno być krótkie i sumaryczne. Tylko istotne części procesu winny być zachowane: wniesienie skargi, wysłuchanie obu stron, przytoczenie dowodów (dokumentów i świadków) i wydanie wyroku na piśmie ${ }^{24}$.

Co do wyroku, ,jeżeli strona pozywająca żąda tylko wstrzymania zapowiedzi i ślubu, jaki druga strona zawrzeć zamierza, i to na podstawie poprzednio zawartych zaręczyn; natenczas sędzia winien zbadać, czy temuż małżeństwu stoi rzeczywiście na zawadzie impedimentum impediens ex sponsalibus, a jeżeli tak jest winien wydać decretum inhibitorium, wzbraniający zawarcia małżeństwa. $\mathrm{W}$ takim razie istnienie przeszkody udowodnić może jeden tylko świadek, byleby był bonae famae i pod przysięgą zeznał, że z pewnością, i nie ze słuchu tylko wie o istnieniu przeszkody"25.

Jeżeli jedna strona twierdzi, że zaręczyny są ważne, druga zaś przeczy, a obie strony żądają od sędziego wyroku stanowczego, wtedy sprawa musi być dokładnie zbadana i jasno udowodniona. Pozywający powinien dowieść całkowicie istnienia zaręczyn. Jak długo tego nie dokona, domniemanie prawne przemawia za wolnością strony pozwanej. Jako środki dowodowe służą: przyznanie się strony pozwanej, zeznania wiarygodnych świadków, dokumenty publiczne i prywatne, jeżeli są wiarygodne $e^{26}$.

\footnotetext{
${ }^{23}$ Sobór Trydencki, Sess. xxiv, Cap. 20.

${ }^{24}$ J. Pelczar, Prawo małżeńskie katolickie, s. 121.

${ }^{25}$ J. Pelczar, Prawo małżeńskie katolickie, s. 122.

${ }^{26}$ J. Pelczar, Prawo małżeńskie katolickie, s. 123.
} 
Jeżeli strona pozwana twierdzi, że zaręczyny były wprawdzie pozornie zawarte, ale że z powodu jakiejś przeszkody od początku były nieważne, wtedy strona ta, a nie strona powodowa, ma udowodnić istnienie tej przeszkody. Przypuszcza się, że akt od początku był ważny, dopóki nie zostanie udowodnione, że było inaczej. Natomiast jeżeli obie strony przyznają, że zaręczyny były zawarte, lecz jedna $z$ nich twierdzi, że ma słuszny powód do ich zerwania, wtedy winna przy pomocy dowodów wykazać, że powód ten jest prawdziwy i de iure wystarczający. „Ponieważ idzie tu o zabezpieczenie wolności indywidualnej i zapobieżenie nieszczęśliwym związkom; przeto do udowodnienia podobnego powodu wystarczą probationes minus concludentes, zwłaszcza wtenczas, jeżeli zaręczyny były tajemnie zawarte, albo strona odstępująca w dobrej wierze przygotowuje się do zawarcia ślubu z trzecią osobą. Co więcej, do wydania wyroku znoszącego pierwsze zaręczyny z powodu zaszłej przeszkody kanonicznej wystarczające jest zeznanie jednego świadka lub opinia stwierdzająca istnienie przeszkody ${ }^{27}$.

\section{Odszkodowanie z powodu zerwania zaręczyn}

Ksiądz Pelczar w swoim podręczniku na temat małżeństwa podejmuje także zagadnienie restytucji za zerwanie zaręczyn. Zrywający zaręczyny - według ustawodawstwa, jakie przywołuje rektor - obowiązany jest do odszkodowania w następujących przypadkach:

- jeżeli strona odstępuje bez słusznego i prawem kanonicznym wskazanego powodu;

- jeżeli ma słuszny powód do odstąpienia, ale ten powód jest wynikiem jego własnej winy, np. wskutek wyuzdanej rozpusty stał się impotentem, albo ściągną przeszkodę affinitatis illegitimae;

- jeżeli powód zaręczyn był przed samymi zaręczynami skrzętnie ukryty, np. jeżeli zaręczona zataiła, że miała z kim innym grzeszne stosunki. Strona winna obowiązana jest do wynagrodzenia, a obowiązek ten nie ustaje nawet wtedy, gdy winna osoba zawarła inne małżeństwo ${ }^{28}$.

Ponadto restytucja może być niezupełna (simplex) lub zupełna (plena). $\mathrm{W}$ przypadku tej pierwszej wynagradza się tylko szkodę poniesioną z przyczyny zaręczyn, np. dary przez stronę niewinną dane drugiej tytułem zaręczyn,

${ }^{27}$ J. Pelczar, Prawo małżeńskie katolickie, s. 124.

${ }^{28}$ J. Pelczar, Prawo małżéskie katolickie, s. 125. 
wydatki z tejże przyczyny poniesione, np. jeżeli druga strona w oczekiwaniu rychłego związku wynajęła większe mieszkanie, przygotowała ucztę weselną itp. W przypadku odszkodowania zupełnego nagradza się nie tylko damnum emergens, ale i lucrum cessans. „W takim razie trzeba przed sędzią duchownym udowodnić, że korzyść była pewną i została niepowrotnie stracona, tak że inny związek małżeński nagrodzić jej nie zdoła. Dzieje się to mianowicie wtenczas: 1/ gdy zrywający zaręczyny, i to bez słusznego powodu, dziewczynę uczciwą pozbawił panieństwa, a sędzia $\mathrm{z}$ obawy nieszczęśliwych skutków nie uważał za stosowne zmusić go do zawarcia $\mathrm{z}$ nią małżeństwa; 2/ kiedy narzeczona przez niesprawiedliwe zerwanie zaręczyn została zniesławiona i nie ma nadziei, aby inne odpowiednie swemu stanowi zawarła małżeństwo; 3/ kiedy takowa z powodu innych okoliczności, które narzeczony mógł przewidzieć, albo które sam spowodował, nie ma widoków wejścia w inne związki”29.

Odszkodowanie zupełne, do której tylko narzeczona może mieć prawo, uskutecznia się w ten sposób, że narzeczony wynagradza jej poniesioną szkodę. W związku z tym składa odpowiedni posag (dotatio). Przy wymiarze wynagrodzenia - według ówczesnych przepisów - należy uwzględnić społeczne i majątkowe położenie obu stron. W przypadku, gdyby strona niewinna żądała wygórowanej kwoty, sędzia winien ją obniżyć według sprawiedliwości, a w razie uporu odesłać stronę do sądu cywilnego ${ }^{30}$.

\section{Wnioski}

1. Ksiądz Józef Sebastian Pelczar jako wykładowca dążył do tego, by wykłady kształtowały samodzielne myślenie studentów. Stąd jego publikacja-podręcznik Prawo małżeńskie katolickie z uwzględnieniem prawa cywilnego obowiązującego w Ausryi, w Prusach $i$ w Królestwie Polskim.

2. Wykładowca akademicki Pelczar postrzega zaręczyny jako obopólną umowę, mocą której mężczyzna i kobieta przyrzekają zaślubić się z sobą w przyszłości. Zaręczyny jako akt przygotowawczy podlegają władzy Kościoła, stąd prawo kościelne określa warunki konieczne do ważnego zawarcia zaręczyn.

3. Przyrzeczenie zaręczyn powinno być prawdziwe, rozważne, dobrowolne, wyrażone obopólnie i powinno mieć formę zewnętrzną.

${ }^{29}$ J. Pelczar, Prawo małżeńskie katolickie, s. 126.

${ }^{30}$ J. Pelczar, Prawo małżeńskie katolickie, s. 127. 
4. Ksiądz Pelczar ze względu na samo zobowiązanie rozróżnia zaręczyny bezwarunkowe i warunkowe.

5. Późniejszy biskup i święty - Józef Sebastian Pelczar - mówiąc o zaręczynach, widzi je w kontekście sakramentu małżeństwa. Stąd - jego zdaniem proboszczowie powinni $\mathrm{z}$ ambony często mówić o warunkach dotyczących ważnego i godziwego zawierania zaręczyn.

6. Nauczanie ks. Pelczara w materii instytucji zaręczyn było wierne nauczaniu Kościoła powszechnego. Walorem jego podręcznika jest zebranie rozproszonych często wiadomości na temat zaręczyn i umieszczenie ich w jednym miejscu. Można powiedzieć, że widzimy w osobie Pelczara prekursora kodyfikacji prawa, która to kodyfikacja nastąpiła dopiero w 1917 roku.

\section{Bibliografia}

Codex Iuris Canonici Pii x Pontificis Maximi iussu digestus Benedicti Papae xv auctoritate promulgatus praefatione, fontium annotatione et indic analytico-alphabetico ab emo Petro Card. Gasparri auctus, Romae мсмхviII.

Ludwicki M.. Biskup, rzecz o św. Józefie Sebastianie Pelczarze, Ząbki 2004.

Pelczar J. S., Wybór pism (Krótka kronika mojego życia, Listy), „Nasza Przeszłość” 29 (1968), s. 90-91.

Pelczar J., Prawo małżeńskie katolickie z uwzględnieniem prawa cywilnego obowiq̨zującego w Ausryi, w Prusach i w Królestwie Polskim, Kraków 1898.

Sobór Trydencki, Sess. xxIv, Cap. 20, w: Dokumenty soborów powszechnych, red.

A. Baron, H. Pietras, Kraków 2005, s. 771.

\section{Streszczenie}

Artykuł jest przykładem wzorcowego wyłożenia tematu przez ks. Pelczara w oparciu o aktualnie obowiązującą doktrynę prawną oraz odpowiednie kazusy ułatwiające zrozumienie tematu. Podstawowym źródłem pracy jest podręcznik ks. Józefa Sebastiana Pelczara pt. Prawo matżeńskie katolickie z uwzględnieniem prawa cywilnego obowiązującego $w$ Ausryi, w Prusach $i w$ Królestwie Polskim wydany w Krakowie w 1898 roku. Na treść przedłożenia składają się następujące kwestie związane z instytucją zaręczyn: wymogi do ważności zaręczyn, forma przyrzeczenia podczas zaręczyn, rodzaje zaręczyn, skutki zawartych zaręczyn, zerwanie zawartych 
zaręczyn, zadania proboszcza przy zawieraniu zaręczyn, rola sądu małżeńskiego w sprawach zaręczyn, odszkodowanie z powodu zerwania zaręczyn. Celem artykułu jest przybliżenie czytelnikowi instytucji zaręczyn widzianej z perspektywy wykładowcy Uniwersytetu Jagiellońskiego, późniejszego rektora tejże uczelni (1882/1883), biskupa i od 2003 roku świętego - Józefa Sebastiana Pelczara.

\section{Słowa kluczowe}

Józef Pelczar, prawo małżeńskie, zaręczyny

\section{Summary}

\section{Institution of Betrothal as Interpreted by Father Józef Pelczar on the Basis of Catholic Canon Law}

The article is an example of an excellent explanation of the subject matter, drawn up by Father Pelczar on the basis of the current legal doctrine and relevant case studies which facilitate a better understanding of the subject. The basic source for the paper is the handbook written by Father Józef Sebastian Pelczar entitled Prawo małżeńskie katolickie z uwzględnieniem prawa cywilnego obowiązującego w Ausryi, $w$ Prusach i $w$ Królestwie Polskim published in Kraków in 1898. The contents discuss the following issues relating to the institution of betrothal: requirements for betrothal validity, form of oath used during betrothal, types of betrothal, effects of concluded betrothal, renouncement of betrothal, tasks of the parish priest during betrothal, role of marital court in betrothal-related cases, compensation for renouncement of betrothal. The aim of the article is to familiarise readers with the institution of betrothal as seen from the perspective of Józef Sebastian Pelczar Jagiellonian University lecturer and subsequently Vice-Chancellor (1882/1883), bishop and - from 2003 - a saint.

\section{Keywords}

Józef Pelczar, marital law, betrothal 